Jurnal IImu Komunikasi

Vol. 12, No. 2

ISSN: 2085 - 4609 (Print), e- ISSN 2656-0208

Journal homepage: bit.ly/UltimaComm

\title{
Hubungan Komunikasi dengan Kepuasan Pernikahan pada Ibu Rumah Tangga Penggemar Tayangan Drama Korea
}

\section{Novaria Maulina \& Atika}

To cite this article:

Maulina, N. \& Atika (2020). Hubungan Komunikasi dengan Kepuasan Pernikahan pada Ibu Rumah Tangga

Penggemar Tayangan Drama Korea, UltimaComm: Jurnal IImu Komunikasi, 12(2), 301-318. DOI

10.31937/ultimacomm.v12i2.1775

Ultimacomm publishes research articles and conceptual paper in the field of communication, mainly digital journalism and strategic communication. It is published twice a year by the Faculty of Communication of Universitas Multimedia Nusantara

Submit your article to this journal $匚$ 


\title{
Hubungan Komunikasi dengan Kepuasan Pernikahan pada Ibu Rumah Tangga Penggemar Tayangan Drama Korea
}

\author{
Novaria Maulina \& Atika \\ Universitas Lambung Mangkurat \\ Email: novaria maulina@ulm.ac.id, atika rusli@ulm.ac.id
}

Received Oct. 6, 2020; Revised on Dec. 23, 2020, Accepted Dec. 29, 2020

\begin{abstract}
Abstrak
Komunikasi dalam pernikahan menjadi salah satu kunci dalam mempertahankan hubungan antarpasangan. Perilaku komunikasi yang mengungkapkan perasaan negatif pada pasangan seperti kritik, sikap membela diri, penghinaan dan penarikan diri bisa menjadi awal dari ketidakpuasan dan perceraian. Sebaliknya, pengungkapan perasaan secara positif memiliki efek tersendiri pada stabilitas hubungan pernikahan dari waktu ke waktu. Tujuan penulisan artikel ini untuk mengukur seberapa besar hubungan komunikasi dengan kepuasan pernikahan pada ibu rumah tangga penggemar drama Korea. Penelitian menggunakan pendekatan kuantitatif dengan tipe eksplanatif. Populasi adalah ibu rumah tangga penggemar tayangan drama Korea dengan jumlah 1000 orang yang diambil dari pendugaan proporsi populasi. Pengumpulan data menggunakan instrumen berupa kuesioner untuk mengukur hubungan antara dua variabel dalam penelitian ini (Komunikasi Pernikahan dan Kepuasan Pernikahan) dengan menggunakan uji korelasi rank Spearman. Berdasarkan hasil penelitian, ditemukan hubungan yang kuat dan signifikan antara Komunikasi Pernikahan dan Kepuasan Pernikahan. Kekuatan hubungan dibuktikan dengan nilai korelasi sebesar 0,692 dan signifikansi berada pada angka 0,000. Hal tersebut menunjukkan bahwa ketika komunikasi pernikahan pasangan semakin baik atau positif, maka pasangan tersebut memiliki kepuasan dalam pernikahannya.
\end{abstract}

Kata Kunci: komunikasi pernikahan, kepuasan pernikahan, drama Korea

\footnotetext{
Abstract

Marriage communication is one of the keys to maintain relationships between spouses. Communication behaviors that reveal negative feelings to partners such as criticism, self-defense, humiliation and withdrawal can be the beginning of dissatisfaction and divorce. On the other hand, positive feelings expression has its own effect on the stability of the marriage relationship over time. The purpose of the study was to measure the correlation of communication with the marriage satisfaction of housewives who were Korean drama fans. The study used a quantitative approach with an explanatory type. The population in this study was housewives who were Korean drama fans. Data
} 
collection through questionnaires and the Spearman's rank correlation test was used to measure the correlation between the two variables in this study (Marriage Communication and Marriage Satisfaction). Based on the study results, there is a strong and significant correlation between Marriage Communication and Marriage Satisfaction. The strength of the correlation is proven with the correlation value of 0.692 and the significance level at 0,000. It shows that when the partner's marriage communication is getting better or positive, then the couple has satisfaction in their marriage.

Keywords: marriage communication, marriage satisfaction, Korean drama

\section{PENDAHULUAN}

Dalam kehidupan perkawinan, komunikasi merupakan salah satu kunci dalam keberlangsungan hubungan, seperti yang diungkapkan oleh Latifa (2015) bahwa salah satu dari tujuh area fungsional untuk menciptakan stabilitas dalam suatu pernikahan adalah komunikasi. Kemampuan mengelola komunikasi antara pasangan dapat menciptakan kesadaran akan kebutuhan pasangannya. Perilaku komunikasi yang mengungkapkan perasaan negatif pada pasangan seperti kritik, sikap membela diri, penghinaan, dan penarikan diri bisa menjadi awal dari ketidakpuasan dan perceraian. Sebaliknya, pengungkapan perasaan secara positif memiliki efek tersendiri pada stabilitas hubungan penikahan dari waktu ke waktu.

Dari kutipan di atas dapat diketahui bahwa kegagalan dalam menerapkan cara komunikasi yang efektif dapat berdampak pada keberlangsungan perkawinan itu sendiri. Hal ini dikuatkan oleh apa yang dikemukakan oleh Stinson et al. (2017) bahwa hubungan suami istri merupakan inti dalam sebuah penikahan dan berdampak pada bagaimana hubungan dalam sebuah keluarga secara keseluruhan, termasuk hubungan antara orang tua dengan anak, serta hubungan antara anak-anak dalam keluarga tersebut.

Banyak kasus perceraian disebabkan oleh konflik yang didasari pada komunikasi interpersonal pasangan. Dikutip dari penelitian yang dilakukan oleh Fauzi (2015), komunikasi interpersonal pemicu perceraian disebabkan oleh banyak hambatan yang mengurangi kualitas komunikasi interpersonal tersebut di antaranya adalah faktor internal berupa tidak mendengarkan atau memperhatikan pasangan, tidak terbuka pada pasangan dan perbedaan pendapat.

Esere et.al. (2014) mengungkapkan tentang hambatan dan solusi yang disarankan untuk komunikasi efektif dalam pernikahan. Hasil penelitian yang telah dilakukan mengungkapkan bahwa hambatan yang paling banyak diekspresikan untuk keefektifan komunikasi dalam pernikahan adalah sering pulang terlambat, nada suara yang kasar selama percakapan, dan mengungkit masa lalu. Adapun solusi yang disarankan adalah untuk hambatan komunikasi yang efektif dalam pernikahan adalah mempertimbangkan 
kontribusi pasangan, memiliki rasa kepercayaan pada pasangan, dan mempertimbangkan pendapat pasangan saat mendiskusikan suatu masalah.

Tulisan ini merupakan hasil penelitian lanjutan dari penelitian yang dilakukan sebelumnya (Maulina N, Atika, Ramadhani M.M, 2020) dengan judul Hubungan Terpaan Tayangan The World of The Married dengan Komunikasi dan Kepuasan Perkawinan pada Penonton Drama Korea. Dari hasil penelitian tersebut, penulis mengkaji lebih dalam mengenai seberapa besar hubungan komunikasi dengan kepuasan pernikahan khususnya pada penggemar drama Korea, dengan jumlah pendugaan proporsi populasi sebesar 1000 orang.

Berdasarkan hasil penelitian sebelumnya diketahui bahwa $68.1 \%$ responden merupakan heavy viewers atau disebut juga penonton fanatik yang menghabiskan waktu menonton drama Korea selama tiga sampai dengan empat jam dalam sehari. Selain itu berdasarkan hasil wawancara yang dilakukan sebagai studi pendahuluan, terungkap bahwa penggemar drama Korea dapat menghabiskan waktu lebih dari sepuluh jam sehari untuk menonton drama Korea seperti yang dikemukakan oleh salah satu responden (DA) dalam wawancara pendahuluan:

"Saya menghabiskan waktu sepanjang malam untuk menonton 12 episode drama Korea, paginya saya sangat mengantuk sampai melupakan pekerjaan rumah, memasak dan mencuci baju hahahaa..."

Dari pernyataan responden di atas dilihat dari banyaknya waktu yang dihabiskan untuk menonton drama Korea. Penulis menduga ada kecenderungan waktu responden yang berkurang untuk berkomunikasi dengan pasangan, namun dalam studi pendahuluan melalui wawancara dengan informan (LS) yang juga merupakan penggemar drama Korea, diperoleh data yang kontra dengan data sebelumnya, yaitu sebagai berikut:

"Menonton drakor itu bagai me time untuk saya, jadi suami sudah paham, kalau saya capek maka release-nya adalah nonton drakor, habis nonton drakor mood jadi bagus lagi secara ga langsung isteri senang, komunikasi juga jadi lancar"

Berdasarkan data pendahuluan di atas, penelitian ini bertujuan mengukur seberapa besar hubungan komunikasi dengan kepuasan pernikahan pada ibu rumah tangga penggemar drama Korea.

\section{TINJAUAN PUSTAKA}

Dalam ilmu sosial, kajian mengenai hubungan keluarga dan pernikahan pada awalnya banyak dikaji oleh ahli-ahli dalam bidang sosialogi dan psikologi. Namun seiring dengan perkembangan tema penelitian yang berfokus pada ketergantungan antarpasangan dan 
interaksi antarpasangan membuat perkembangan penelitian dalam bidang komunikasi perkawinan menjadi sangat tinggi (Berger, Roloff dan Ewoldsen, 2014).

Menurut Luthfi (2017) keberhasilan komunikasi interpersonal antara suami dan istri dalam perkawinan akan menumbuhkan kedekatan hubungan interpersonal yang baik pula dalam keluarga. Untuk itu, komunikasi interpersonal menjadi kunci utama dalam menumbuhkan kedekatan hubungan interpersonal antara suami dan istri.

Menurut Rakhmat (2007) terdapat tiga faktor yang dapat menumbuhkan hubungan interpersonal berkaitan dengan upaya untuk mencapai komunikasi interpersonal yang efektif dalam keluarga, yaitu:

1. Sikap saling percaya antar pasangan. Dalam perkawinan sikap percaya antarpasangan akan terbangun dengan baik jika diiringi dengan kejujuran dan kesediaan untuk saling menerima kekurangan dan kelebihan satu sama lain.

2. Sikap saling mendukung dan saling menghargai akan membuat pasangan dapat menghilangkan sikap defensif atau sikap yang cenderung untuk menutup diri dalam setiap aktivitas komunikasi yang dilakukan.

3. Sikap terbuka antarpasangan dapat mendorong terciptanya saling pengertian, kesepahaman bersama dan saling mengembangkan kualitas hubungan interpersonal pasangan untuk mencapai komunikasi interpersonal yang efektif dalam keluarga.

Taniguchi dan Kaufman (2014) dalam artikel ilmiah dengan judul "Gender role attitudes, troubles talk, and marital satisfaction in Japan" menjelaskan mengapa gaya komunikasi menjadi faktor penting dalam interaksi antara suami istri. Cara masing-masing pasangan dalam mengungkapkan persetujuan, memutuskan kesepakatan, dan bagaimana pasangan berinteraksi saat menghadapi masalah adalah kunci dalam mencapai kepuasan pada pernikahan.

Menurut Moorman (2011) ketika pasangan saling menerapkan self disclosure maka akan tercipta pemahaman dan satu pengertian yang sama, merasa dipahami yang tidak dapat diukur secara akurat. Namun, komunikasi perkawinan merupakan kombinasi dari harapan, kepercayaan dan persepsi.

Dampak yang lebih luas dari komunikasi perkawinan menurut Seiter et.al. (2019) adalah pada dengan kesehatan mental dan juga imunitas tubuh pada pasangan. Pola komunikasi yang baik dalam perkawinan berkorelasi pada perasaan sehat secara mental dan fisik serta meningkatkan imunitas.

Menurut Yucel (2017) penting bagi pasangan dalam perkawinan terutama bagi mereka yang bekerja untuk memiliki kesehatan mental yang baik karena akan berdampak pada cara pasangan dalam terutama saat mengatasi konflik dalam perkawinan. Vangelisti (2004) mengungkapkan dalam hubungan dengan kepuasan hubungan dalam 
perkawinan, komunikasi nonverbal dinilai lebih memiliki hubungan yang kuat daripada komunikasi verbal.

Pada zaman modern saat ini banyak orang menganggap bahwa menikah bukan sebuah kewajiban, namun lebih kepada keputusan yang dibentuk secara alami melalui perasaan cinta dan kesadaran dalam pengambilan keputusan oleh pasangan. Kepuasan dalam pernikahan menjadi faktor kunci dalam menjaga kualitas dan stabilitas hubungan pernikahan (Li \& Fung, 2011).

Kepuasan perkawinan dapat didefinisikan sebagai proses adaptasi terhadap pasangan dengan sedemikian rupa untuk menghindari atau untuk menyelesaikan konflik sehingga pasangan merasakan cukup puas satu sama lain dengan pernikahan. Beberapa faktor yang tekait dengan kepuasan pernikahan adalah hubungan dengan mertua, komunikasi, pemahaman, kompromi, perbedaan gender, pendidikan, penghasilan ganda, status keuangan suami, hubungan seksual, persepsi diri, pembagian peran dalam rumah tangga, waktu yang dihabiskan bersama dan dukungan dari pasangan (Ayub, 2010).

Menurut riset yang dilakukan oleh Van Den Troost, Vermulst, Gennis, dan Matthiss (2005) beberapa indikator dalam mengukur kepuasan pernikahan dapat dilihat pada cara pasangan memperlakukan satu sama lain dan harapan akan keberlangsungan hubungan. Menurut Brisini dan Solomon (2021) kepuasan pernikahan sering dihubungkan dengan konflik dalam pernikahan. Kualitas suatu hubungan terkait dengan cara menyelesaikan konflik terutama ketika hubungan sedang menghadapi suatu masalah. Di samping itu, kesetaraan dalam hubungan, serta interaksi yang dilakukan oleh pasangan, adalah hal yang penting dalam menjaga kualitas pernikahan.

Sebuah pernikahan yang stabil membutuhkan komunikasi (Gonczarowski et.al., 2019). Menurut Robinson dan Blanton (2003) beberapa faktor penting untuk mencapai kepuasan perkawinan, antara lain adalah:

1. Keintimanan secara emosional, fisik, serta spiritual. Keintiman dapat direpresentasikan dengan saling berbagi baik dalam minat, aktivitas, pemikiran, perasaan suka dan duka. Keintiman pasangan dibangun melalui keterlibatan pasangan suami istri dalam berbagai keadaan baik saat menyenangkan ataupun saat menyedihkan. Keintiman pasangan dalam perkawinan juga bisa ditingkatkan melalui kebersamaan, saling ketergantungan, saling mendukungan, dan saling memberi perhatian. Walaupun pasangan memiliki keintiman yang tinggi, bukan berarti pasangan harus selalu melakukan berbagai hal bersama. Suami maupun istri juga berhak melakukan aktivitas dan minat yang berbeda dengan pasangannya.

2. Komitmen. Dalam perkawinan komitmen tidak hanya ditujukan terhadap pernikahan sebagai sebuah institusi sosial, tetapi juga komitmen terhadap pasangan, sehingga diperlukan kejujuran dan kesetiaan sebagai bentuk tanggung jawab. 
3. Komunikasi. Untuk menajalankan perkawinan, pasangan suami istri harus memiliki kemampuan berkomunikasi yang baik mencakup berbagi pikiran dan perasaan, bersama-sama mendiskusikan masalah, dan mendengarkan sudut pandang satu sama lain. Pasangan yang mampu berkomunikasi secara konstruktif akan dapat mengantisipasi kemungkinan terjadinya konflik.

4. Kongruensi. Untuk dapat mencapai kepuasan pernikahan, pasangan harus memiliki kongruensi atau bisa diartikan kesesuaian dalam mempersepsi kekuatan dan kelemahan dari hubungan perkawinannya. Pasangan yang mempersepsikan hubungan perkawinannya kuat, cenderung akan merasa lebih nyaman dengan perkawinannya.

5. Keyakinan beragama. Pada umumnya pasangan meyakini bahwa keyakinan beragama merupakan unsur penting dalam sebuah perkawinan. Nilai-nilai agama yang dibagikan dan dianut oleh pasangan dan kemudian diimplementasikan secara bersama, seperti melakukan ibadah keagaaman bersama-sama dapat menciptakan ikatan kuat dan nyaman di antara mereka, serta berpengaruh positif bagi kepuasan pernikahan.

Menurut penelitian yang dilakukan oleh Srisusanti dan Zulkaida (2013) terdapat beberapa faktor dominan yang mempengaruhi kepuasaan perkawinan dari perspektif istri, yaitu:

1. Hubungan personal. Fondasi awal dalam perkawinan adalah hubungan personal dari suami istri itu sendiri untuk mencapai tujuan perkawinan yang bahagia. Jika hubungan antara pasangan suami istri telah terjalin dengan baik, maka dapat diasumsikan bahwa perkawinan itu akan menjadi perkawinan yang bahagia.

2. Prinsip dan nilai keagamaan. Nilai-nilai agama yang diyakini oleh pasangan suami istri dan diamalkan bersama dalam pernikahan dipercaya akan menuntun pasangan pada ketenteraman, kebahagiaan, dan kesejahteraan dalam berumah tangga. Kegiatan keagamaan mempengaruhi tingkat kepuasan perkawinan karena kesamaan agama pasangan akan memudahkan mereka untuk melakukan aktivitas keagamaan secara bersama-sama, seperti salat berjamaah dan mengaji bersama untuk umat Islam, beribadah ke gereja bersama-sama bagi kaum nasrani, ataupun menghadiri dan melaksanakan kegiatan keagamaan lainnya bersama keluarga.

3. Hubungan seksual. Dalam perkawinan hubungan seksual merupakan salah satu unsur penting. Tanpa kehidupan seksual suami istri, perkawinan menjadi tidak utuh. Banyak pasangan yang mengalami ketegangan dan konflik dalam perkawinan, bahkan perceraian karena merasa tidak memiliki kehidupan seksual yang sehat. Dalam perkawinan, hubungan seksual merupakan ekspresi dari perasaan kasih sayang dan cinta yang dirasakan.

4. Kesesuaian peran dan harapan. Penting bagi suami istri untuk mengatur pembagian tugas dan peran dalam perkawinan secara adil agar perkawinan berjalan sesuai dengan apa yang ia harapkan. Saat pasangan menjalankan peran sesuai harapan dan kesepakatan bersama, mereka akan cenderung mendapatkan kepuasan. 
5. Komunikasi. Faktor penting dalam menjalankan perkawinan adalah komunikasi. Pola komunikasi yang baik dalam perkawinan akan menciptakan kepuasan perkawinan. Kemampuan berkomunikasi yang baik dibangun melalui interaksi yang intens pasangan, misalnya saling menceritakan apa yang dialami sepanjang hari.

6. Kesamaan minat. Penting bagi pasangan untuk tetap meluangkan waktu melakukan aktivitas bersama-sama dengan pasangannya meskipun mereka sibuk bekerja. Kesamaan minat berarti sejauh mana pasangan dapat melakukan aktivitas secara bersama-sama, seperti berlibur, atau melakukan hobi secara bersama-sama, misalnya menonton film ke bioskop.

7. Kemampuan mengatasi konflik. Dalam setiap perkawinan, pasangan akan dihadapkan pada masalah dan konflik. Kemampuan mengatasi konflik berkaitan dengan bagaimana pasangan dapat mencari solusi yang disepakati bersama oleh kedua belah pihak.

8. Keuangan merupakan faktor yang cukup berpengaruh pada kepuasan perkawinan. Untuk menyokong jalannya rumah tangga diperlukan biaya yang berkaitan dengan kebutuhan-kebutuhan domestik. Perekonomian keluarga yang memadai akan mendukung tercapainya kepuasan perkawinan, maka dari itu kesepakatan pasangan suami istri mengenai pengaturan dan pengendalian keuangan perlu diperhatikan. Ketiadaan pengaturan dan pengendalian masalah keuangan secara baik berpotensi menjadi sumber konflik.

Dari sisi lain, Boyce et al. (2016) mengungkapkan hasil penelitiannya tentang kepuasan pernikahan. Hasil temuannya menunjukkan bahwa wanita introver dan pria ekstrover mengalami kepuasan hidup dalam jangka panjang setelah menikah.

Berdasarkan sejumlah hasil temuan yang telah diungkapkan, pertanyaan yang dirumuskan dalam penelitian ini adalah: seberapa besar hubungan komunikasi dengan kepuasan pernikahan pada ibu rumah tangga penggemar drama Korea?

\section{METODE}

Penelitian menggunakan pendekatan kuantitatif dengan tipe ekplanatif, yang mencari hubungan dua variabel, yaitu variabel Komunikasi Pernikahan (X) dan variabel Kepuasan Pernikahan $(\mathrm{Y})$. Populasi dalam penelitian ini adalah penggemar tayangan drama Korea dengan status sosial ibu rumah tangga.

Dalam penelitian ini, pengertian ibu rumah tangga merujuk pada apa yang dikemukakan oleh Howard (2015, p. 101) bahwa ibu rumah tangga bukan hanya "Ibu rumah tangga" dalam pengertian tradisional, namun mereka adalah wanita yang bersemangat, ibu-ibu yang menyayangi anak-anaknya, dan juga berperan untuk menghasilkan uang dengan bekerja di luar rumah atau sebagai pengusaha yang bekerja dari rumah. Dari konsep ini dapat diketahui bahwa konteks ibu rumah tangga dapat dipahami dengan lebih luas. Ibu rumah tangga tidak dipahami sebatas seorang wanita yang mengatur penyelenggaraan 
berbagai macam pekerjaan rumah tangga atau istri (lbu) yang hanya mengurusi berbagai pekerjaan dalam rumah tangga dan tidak bekerja dikantor.

Untuk menentukan sampel dari jumlah populasi yang besar maka menggunakan Rumus Yamane (Kriyantono, 2020) berikut:

$$
\mathrm{n}=\frac{N}{N d^{2}+1}
$$

Keterangan:

$\mathrm{n}=$ sampel;

$\mathrm{N}=$ pendugaan proporsi populasi;

$\mathrm{d}=$ tingkat kesalahan

Jumlah N sebanyak 1000, sehingga jumlah sampel penelitian sebanyak 135,1 dibulatkan menjadi 135. Adapun teknik penarikan sampel menggunakan simple random sampling dengan melakukan filter data awal responden, yaitu penggemar tayangan drama Korea. Kuesioner disebarkan secara online melalui forum (grup) media sosial penggemar drama Korea. Adapun teknik pengumpulan data dalam penelitian ini menggunakan kuesioner yang berisi pernyataan dengan empat skala, yaitu sangat sesuai, sesuai, tidak sesuai, dan sangat tidak sesuai. Hasil uji reliabilitas sebesar 0,803 menunjukkan bahwa instrumen penelitian yang digunakan termasuk reliable. Uji validitas per item $>0,6$ menunjukkan bahwa item pernyataan yang ada dalam instrumen dinyatakan valid.

Data dianalisis menggunakan analisis korelasi untuk menentukan kuat atau lemahnya hubungan antara variabel Komunikasi Pernikahan $(X)$ dan Kepuasan Pernikahan (Y). Untuk menentukan kategori dari dua variabel tersebut dibuat kelas interval sebesar 1 , sehingga nilai 1,0 - 2,0 termasuk kategori rendah; 2,1 - 3,0 termasuk sedang; dan 3,1 4,0 termasuk kategori tinggi.

\section{HASIL}

Sebagaimana tujuan penelitian ini adalah untuk mengukur besarnya hubungan antara variabel komunikasi pernikahan dengan variabel kepuasan pernikahan pada ibu rumah tangga penggemar drama Korea, maka pada bagian hasil ini disajikan data tentang ratarata frekuensi pernyataan responden berdasarkan kategori open communication dan negative communication, rata-rata frekuensi pernyataan responden berdasarkan variabel kepuasan pernikahan, nilai mean variabel komunikasi dan kepuasan pernikahan, dan nilai korelasi variabel komunikasi pernikahan dengan kepuasan pernikahan. Terlebih dahulu, bagian ini menyajikan data karakteristik responden yang menjadi sampel dalam penelitian ini, yang disajikan berdasarkan usia, domisili, pekerjaan, dan usia pernikahan, yang semuanya dirangkum dalam Tabel 1. 
Tabel 1. Karakteristik Responden berdasarkan Usia, Domisili, Pekerjaan, dan Usia Pernikahan

\begin{tabular}{|c|c|c|}
\hline \multicolumn{3}{|c|}{$\begin{array}{c}\text { Karakteristik Responden berdasarkan Usia, Domisili, } \\
\text { Pekerjaan, Usia Pernikahan }\end{array}$} \\
\hline Usia & $\mathrm{F}$ & $\%$ \\
\hline $20-30$ tahun & 57 & 42 \\
\hline $31-40$ tahun & 74 & 55 \\
\hline$>40$ tahun & 4 & 3 \\
\hline Domisili (Pulau) & $\mathrm{F}$ & $\%$ \\
\hline Jawa & 52 & 38,5 \\
\hline Kalimantan & 71 & 52,6 \\
\hline Papua & 1 & 0,7 \\
\hline Sulawesi & 8 & 5,9 \\
\hline Sumatera & 3 & 2,2 \\
\hline Pekerjaan & $\mathrm{F}$ & $\%$ \\
\hline PNS & 29 & 21,5 \\
\hline Swasta & 38 & 28,1 \\
\hline Guru & 4 & 3,0 \\
\hline Dosen & 10 & 7,4 \\
\hline Ibu Rumah Tangga & 47 & 34,8 \\
\hline Mahasiswa & 2 & 1,5 \\
\hline Lainnya & 5 & 3,7 \\
\hline Usia Pernikahan & $F$ & $\%$ \\
\hline$<1$ tahun & 14 & 10,4 \\
\hline $1-3$ tahun & 24 & 17,8 \\
\hline $4-5$ tahun & 25 & 18,5 \\
\hline$>5$ tahun & 72 & 53,3 \\
\hline
\end{tabular}

Sumber: Hasil Penelitian (2020) 
Berdasarkan Tabel 1 terlihat bahwa responden didominasi oleh usia $>30$ tahun, dengan sebaran responden yang berusia 20 - 30 tahun berjumlah $42 \%$, 31 - 40 tahun sebanyak $55 \%$, dan usia di atas 40 tahun sebanyak 3\% dari 135 jumlah responden yang menjadi sampel dalam penelitian ini. Terlihat dari sebaran berdasarkan lokasi domisili bahwa responden mayoritas berada di Pulau Kalimantan (52,6\%) dan Pulau Jawa (38,5\%). Selebihnya berdomisili di Pulau Sulawesi, Sumatera, dan Papua.

Berdasarkan pekerjaan, mayoritas responden adalah ibu rumah tangga (35\%), pekerja sektor swasta (28\%), serta PNS (21\%). Selebihnya bekerja sebagai guru, dosen, mahasiswa, dan pebisnis online.

Bila dilihat dari data usia pernikahan, mayoritas responden telah memiliki usia pernikahan $>5$ tahun (53\%). Selebihnya (47\%) adalah responden dengan usia pernikahan $<1$ tahun, 1-3 tahun, dan 4-5 tahun.

Komunikasi pernikahan dalam penelitian ini diukur dengan melihat pada indikator open communication, atau interaksi dengan pasangan yang bersifat positif, dan negative communication, atau interaksi yang bersifat negatif. Enam pernyataan untuk indikator open communication yang diungkap dalam penelitian ini, yaitu:

1. Sering berbicara pada pasangan mengenai permasalahan pribadi

2. Sering berbicara pada pasangan mengenai topik yang menarik

3. Sering berbicara pada pasangan mengenai hal menyenangkan yang dialami setiap hari

4. Pasangan sering menunjukkan perasaannya

5. Pasangan sering menunjukkan pengertiannya

6. Sering meminta masukan pada pasangan untuk memecahkan masalah yang dihadapi

Adapun pernyataan yang termasuk negative communication sebanyak delapan item, yaitu:

1. Pasangan sering menyalahkan ketika bertengkar

2. Pasangan sering marah ketika berbeda pendapat

3. Pasangan sering menekan dengan pemikiran/kehendaknya

4. Pasangan saling memotong pembicaraan saat sedang berbicara bersama

5. Pasangan sering mencari kesalahan

6. Pasangan sering menggunakan nada yang menunjukkan ketidaksukaan ketika berbicara

7. Pasangan sering berpura-pura sedang mendengarkan padahal sebenarnya tidak mendengarkan

8. Pasangan sering merajuk. 
Rata-rata frekuensi pernyataan responden tentang komunikasi mereka dengan pasangan disajikan pada Tabel 2.

Tabel 2. Rata-rata frekuensi pernyataan responden berdasarkan kategori open communication dan negative communication

\begin{tabular}{lcc}
\hline \multicolumn{3}{c}{ Variabel Komunikasi Pernikahan } \\
\hline Open Communication & $\mathrm{F}$ & $\%$ \\
\hline Sangat sesuai & 78 & 57,8 \\
Sesuai & 37,7 & 27,9 \\
Tidak sesuai & 16,7 & 12,3 \\
Sangat tidak sesuai & 2,7 & 2 \\
\hline Negative Communication & $\mathrm{F}$ & $\%$ \\
\hline Sangat sesuai & 3,6 & 2,7 \\
Sesuai & 14,6 & 10,8 \\
Tidak sesuai & 49,2 & 36,5 \\
Sangat tidak sesuai & 67,5 & 49,9 \\
\hline
\end{tabular}

Sumber: Hasil Penelitian (2020)

Berdasarkan data pada Tabel 2 terlihat bahwa 85,7\% responden (kategori sesuai dan sangat sesuai) menyatakan bahwa mereka berkomunikasi yang sifatnya terbuka dengan pasangan, namun terdapat $14,3 \%$ responden (kategori tidak sesuai dan sangat tidak sesuai) yang masih tertutup dalam berkomunikasi dengan pasangan, baik dalam berbagi permasalahan pribadi dan yang lainnya.

Adapun untuk indikator negative communication, sejumlah $86,4 \%$ responden menyatakan tidak sesuai dan sangat tidak sesuai dengan pernyataan yang ada. Hal tersebut menunjukkan bahwa mereka tidak membangun komunikasi yang negatif dengan pasangannya. Sebanyak $13,5 \%$ responden menyatakan bahwa mereka masih sering melakukan komunikasi bersifat negatif dengan pasangan.

Kepuasan pernikahan diukur dengan melihat hasil dari pernyataan responden tentang kepuasan mereka dengan pasangan selama menikah. Sembilan pernyataan kepuasan pernikahan yang yang diungkap dalam penelitian ini, yaitu:

1. Memiliki keinginan untuk selalu bersama selamanya dengan pasangan

2. Puas dalam cara memperlakukan satu sama lain

3. Berharap memiliki hubungan yang lebih dari saat ini 
4. Merasa hubungan tidak sulit untuk berhasil

5. Akan tetap memilih pasangan jika dapat memilih lagi

6. Merasa hubungan dapat menjadi lebih baik

7. Puas dengan hubungan saat ini

8. Puas dengan apresiasi yang didapatkan dari pasangan

9. Tidak pernah menyesali hubungan dengan pasangan.

Rata-rata frekuensi pernyataan responden tentang kepuasan pernikahan disajikan pada Tabel 3.

Tabel 3. Rata-rata frekuensi pernyataan responden berdasarkan variabel kepuasan pernikahan

\section{Variabel Kepuasan Pernikahan}

\begin{tabular}{lcc}
\hline & $F$ & $\%$ \\
\hline Sangat sesuai & 89,2 & 66,1 \\
Sesuai & 31,7 & 23,4 \\
Tidak sesuai & 11,4 & 8,5 \\
Sangat tidak sesuai & 2,7 & 2 \\
\hline Total & 135 & 100 \\
\hline
\end{tabular}

Sumber: Hasil Penelitian (2020)

Berdasarkan data pada Tabel 3 terlihat bahwa 10,5\% responden menyatakan ketidakpuasan pernikahan yang mereka jalani dengan pasangan. Sejumlah responden mengungkapkan ketidakpuasan mereka dengan perlakuan pasangan terhadap dirinya, juga ketidakpuasan mereka dalam hal apresiasi yang didapatkan dari pasangannya.

Namun demikian, hasil penelitian menunjukkan bahwa hampir $90 \%$ responden menyatakan puas dengan pernikahan yang mereka jalani dengan pasangan. Hal tersebut terlihat pada rata-rata persentase pernyataan yang sangat sesuai dan pernyataan sesuai pada Tabel 3. 
Tabel 4 menyajikan nilai mean untuk setiap indikator dari variabel komunikasi pernikahan dan kepuasan pernikahan.

Tabel 4. Nilai Mean Variabel Komunikasi dan Kepuasan Pernikahan

\begin{tabular}{ccc}
\hline & Nilai Mean Variabel & \\
\hline Komunikasi pernikahan & Mean & Keterangan \\
Open communication & 3,37 & Tinggi \\
Negative communication & 3,41 & Tinggi \\
Kepuasan pernikahan & 1,66 & Rendah \\
\hline
\end{tabular}

Sumber: Hasil Penelitian (2020)

Berdasarkan nilai mean variabel yang disajikan pada Tabel 4, terlihat bahwa secara keseluruhan variabel Komunikasi Pernikahan ibu rumah tangga penggemar tayangan drama Korea tergolong tinggi, dengan nilai mean 3,37. Nilai mean untuk indikator open communication sebesar 3,41, termasuk dalam kategori tinggi. Hal tersebut menunjukkan bahwa komunikasi yang terbangun dalam pernikahan ibu rumah tangga penggemar tayangan drama Korea termasuk terbuka.

Adapun nilai mean untuk indikator negative communication sebesar 1,66 tergolong rendah. Hal tersebut menunjukkan bahwa komunikasi pernikahan yang sifatnya negatif pada pasangan ibu rumah tangga penggemar tayangan drama Korea sangat minim. Nilai mean variabel kepuasan pernikahan sebesar 3,54 sebagaimana yang ditunjukkan dalam Tabel 4. Hal tersebut membuktikan bahwa pasangan ibu rumah tangga penggemar tayangan drama Korea memiliki kepuasan yang tergolong tinggi dalam pernikahannya.

Sebagaimana tujuan dalam penelitian ini, yaitu untuk mengukur seberapa besar hubungan komunikasi dengan kepuasan pernikahan pada ibu rumah tangga penggemar drama Korea, maka dilakukan uji korelasi Rank Spearman, yang hasilnya disajikan pada Tabel 5.

Tabel 5. Nilai Korelasi Variabel Komunikasi Pernikahan dengan Kepuasan Pernikahan

\begin{tabular}{lcc}
\hline \multicolumn{2}{c}{ Nilai Korelasi Variabel Penelitian } \\
& Nilai Korelasi & Sig. \\
\hline $\begin{array}{l}\text { Komunikasi pernikahan dan } \\
\text { Kepuasan Pernikahan }\end{array}$ & 0,692 & 0,000 \\
\hline
\end{tabular}

Sumber: Hasil Penelitian (2020) 
Berdasarkan Tabel 5, hasil uji korelasi yang dilakukan pada dua variabel (Komunikasi Pernikahan dan Kepuasan Pernikahan) dalam penelitian ini, ditemukan hasil dengan nilai korelasi 0,692 dan signifikansi berada pada angka 0,000. Hal tersebut menunjukkan bahwa komunikasi pernikahan memiliki hubungan yang kuat dan signifikan dengan kepuasan pernikahan, artinya ketika komunikasi pernikahan pasangan semakin baik atau positif, maka pasangan tersebut memiliki kepuasan dalam pernikahannya.

\section{PEMBAHASAN}

Salah satu faktor yang mendukung keberhasilan komunikasi antarpasangan adalah sikap terbuka (Rakhmat, 2007). Sikap terbuka mendorong untuk terciptanya saling pengertian, saling memahami perasaan, sikap, serta pemikiran pasangan. Adanya sikap terbuka dapat mengembangkan kualitas hubungan antara pasangan untuk mencapai komunikasi interpersonal yang efektif dalam keluarga.

Dari hasil penelitian diketahui bahwa 85,7 \% responden menyatakan bahwa mereka melakukan komunikasi yang sifatnya terbuka dengan pasangan termasuk mengenai kegemaran menonton drama Korea sebagai bentuk stress release terhadap kesibukan sehari-hari. Dengan adanya keterbukaan, pasangan dapat memahami dan memberikan ruang bagi para responden untuk menonton drama Korea sebagai bentuk stress release dan me time dari kesibukan sehari-hari. Seperti dibahas di bagian hasil, responden pada penelitian ini memiliki berbagai macam latar bidang pekerjaan, seperti pegawai negeri sipil, pebisnis, ibu rumah tangga, guru, dosen, dan mahasiswa.

Keterbukaan antarpasangan dapat dibangun melalui komunikasi interpersonal, seperti yang dikemukakan oleh Robinson dan Blanton (2003) bahwa dalam perkawinan diperlukan kemampuan berkomunikasi yang baik mencakup berbagi pikiran dan perasaan, bersama-sama mendiskusikan masalah, dan mendengarkan sudut pandang satu sama lain. Pasangan yang mampu berkomunikasi secara konstruktif akan dapat mengantisipasi kemungkinan terjadinya konflik.

Dengan komunikasi yang terbuka, pasangan dapat saling mengutarakan perasaan dan pemikiran. Sesuai dengan hasil penelitian, komunikasi terbuka yang dilakukan oleh responden berada dalam kategori tinggi. Keterbukaan yang dimaksud adalah dengan menceritakan masalah pribadi yang sedang dihadapi dan memberikan kesempatan pada pasangan untuk memberikan solusi atas masalah yang dihadapi. Selain itu, responden juga berinteraksi dengan membericarakan hal-hal yang menyenangkan yang dialami setiap hari dan berupaya untuk sering menunjukkan perasaan dan pengertian.

Seperti yang dikemukakan oleh Li \& Fung (2011), pada zaman modern di mana perkawinan dianggap bukan suatu kewajiban namun lebih pada keputusan yang dilandasi rasa cinta dan kemauan untuk berkomitmen dalam jangka waktu yang sangat panjang, maka penting bagi pasangan dalam sebuah perkawinan untuk selalu saling 
mengungkapkan perasaan satu sama lain sehingga rasa cinta yang menjadi fondasi dari perkawinan dapat terus dirasakan. Pengungkapan perasaan secara positif memiliki efek tersendiri pada stabilitas hubungan penikahan dari waktu ke waktu.

Vangelisti (2004) mengungkapkan dalam hubungan dengan kepuasan hubungan dalam perkawinan, komunikasi nonverbal dinilai lebih memiliki hubungan yang kuat dari pada komunikasi verbal. Keintiman secara fisik dapat dijadikan salah satu bentuk pengungkapan perasaan secara nonverbal pada pasangan. Keintiman fisik dan hubungan seksual menjadi salah satu faktor yang menentukan kepuasan pernikahan (Srisusanti \& Zulkaida, 2013; Robinson \& Blanton, 2003).

Hal-hal yang terkandung dalam keintiman adalah saling berbagi, baik dalam minat, aktivitas, pemikiran, perasaan, suka dan duka. Keintiman pasangan dapat tercipta melalui keterlibatan pasangan satu sama lain dalam berbagai situasi baik menyenangkan maupun menyedihkan. Keintiman pasangan dalam perkawinan juga dapat ditingkatkan melalui kebersamaan, saling ketergantungan, saling mendukungan dan memberi perhatian. Meskipun pasangan memiliki keintiman yang sangat tinggi, bukan berarti pasangan selalu melakukan berbagai hal bersama. Suami atau istri juga berhak melakukan aktivitas dan minat yang berbeda dengan pasangannya, seperti halnya para responden yang memiliki minat menonton drama Korea.

Berdasarkan hasil penelitian, nilai mean variabel kepuasan pernikahan sebesar 3,54 membuktikan bahwa pasangan ibu rumah tangga penggemar tayangan drama Korea memiliki kepuasan yang tergolong tinggi dalam pernikahannya. Proses interaksi pasangan dalam pernikahan menjadi sangat relevan dengan kepuasan dan stabilitas hubungan.

Perilaku komunikasi yang mengungkapkan perasaan negatif pada pasangan seperti kritik, sikap membela diri, penghinaan, dan penarikan diri bisa menjadi awal dari ketidakpuasan dan perceraian. Sebaliknya, pengungkapan perasaan secara positif memiliki efek tersendiri pada stabilitas hubungan penikahan dari waktu ke waktu.

Hal ini sesuai dengan hasil penelitian yang menunjukkan bahwa lebih $80 \%$ responden menyatakan mereka tidak membangun komunikasi yang negatif dengan pasangannya. Komunikasi yang terbuka dapat dilakukan dengan saling membicarakan mengenai permasalahan pribadi, hal-hal yang menyenangkan yang dialami setiap hari pada pasangan, saling menunjukkan pengertiannya; dan meminta masukan pada pasangan untuk memecahkan masalah yang dihadapi.

Kegemaran menonton drama Korea bagi ibu rumah tangga, di mana mereka menghabiskan tiga sampai empat jam sehari, dapat menjadi sumber konflik jika tidak dikomunikasikan dengan pasangan. Namun, mayoritas responden pada penelitian ini dapat mengkomunikasikan kegemaran mereka kepada pasangan sehingga pasangan dapat memahami dan memberikan pengertian. 
Menurut Ayub (2010), kepuasan perkawinan dapat didefinisikan sebagai proses adaptasi terhadap pasangan dengan sedemikian rupa untuk menghindari atau untuk menyelesaikan konflik sehingga pasangan merasakan cukup puas satu sama lain dengan pernikahan. Salah satu faktor yang terkait dengan kepuasan pernikahan adalah komunikasi, sejalan dengan hasil penelitian ini yang menunjukkan nilai korelasi 0,692 dan signifikansi berada pada angka 0,000. Hal tersebut menunjukkan bahwa komunikasi pernikahan memiliki hubungan yang kuat dan signifikan dengan kepuasan pernikahan. Artinya ketika komunikasi pernikahan pasangan semakin baik atau positif, maka pasangan tersebut memiliki kepuasan dalam pernikahannya.

Menurut Brisini dan Solomon (2021) kepuasan pernikahan sering dihubungkan dengan konflik dalam pernikahan, kualitas suatu hubungan berhubungan dengan cara menyelesaikan konflik terutama ketika hubungan sedang menghadapi suatu masalah. Selain itu, kesetaraan dalam hubungan, serta interaksi yang dilakukan oleh pasangan, adalah hal yang penting dalam menjaga kualitas pernikahan. Dapat dilihat bahwa komunikasi adalah unsur penting dan tidak dapat dielakkan dalam menjaga stabilitas dan kualitas hubungan. Sebaliknya komunikasi yang buruk akan menciptakan konflik antarpasangan sehingga perlu dihindari.

\section{SIMPULAN}

Berdasarkan hasil penelitian, dapat disimpulkan bahwa pasangan ibu rumah tangga penggemar tayangan drama Korea memiliki komunikasi dan kepuasan pernikahan yang cukup tinggi. Hasil uji korelasi menunjukkan bahwa terdapat hubungan yang kuat dan signifikan antara Komunikasi Pernikahan dan Kepuasan Pernikahan.

Kekuatan hubungan dibuktikan dengan nilai korelasi sebesar 0,692 dan signifikansi berada pada angka 0,000. Hal tersebut menunjukkan bahwa ketika komunikasi pernikahan pasangan semakin baik atau positif, maka pasangan tersebut memiliki kepuasan dalam pernikahannya. Komunikasi perkawinan dilakukan dengan terbuka dengan saling menceritakan masalah pribadi yang sedang dihadapi dan melibatkan pasangan untuk memberikan solusi.

Penelitian ini terbatas pada penggambaran seberapa besar hubungan komunikasi dengan kepuasan pernikahan pada ibu rumah tangga penggemar tayangan drama Korea. Pada masa yang akan datang dapat dilakukan penelitian lanjutan dengan metode kualitatif untuk mengeksplorasi lebih jauh bagaimana strategi ibu rumah tangga penggemar drama Korea, khususnya pada katageori heavy viewer dalam meminimalisir konflik melalui komunikasi guna mempertahankan kepuasan pernikahan. 


\section{REFERENSI}

Ayub, N. (2010). Development of Marital Satisfaction Scale. Pakistan Journal of Clinical Psikology, 9(1), 19-34.

Boyce, C.J., Wood, A.M., \& Ferguson, E. (2016). For better or for worse: The moderating effects of personality on the marriage-life satisfaction link. Personality and Individual Differences, 97, 61-66. https://doi.org/10.1016/j.paid.2016.03.005

Brisini, K.S.C., \& Solomon, D.H. (2021). Distinguishing relational turbulence, marital satisfaction, and parenting stress as predictors of ineffective Arguing among parents of children with autism. Journal of Social and Personal Relationships, 38(1), 65-83. https://doi.org/10.1177/0265407520958197

Esere, M.O., Yeyeodu,A.-, \& Oladun, C. (2014). Obstacles and Suggested Solutions to Effective Communication in Marriage as Expressed by Married Adults in Kogi State, Nigeria. Procedia - Social and Behavioral Sciences, 114, 584-592. https://doi.org/10.1016/j.sbspro.2013.12.751

Fauzi, M. (2015). Fenomena Komunikasi Interpersonal Sebagai Penyebab Perceraian Pada Pasangan Yang Sudah Bercerai Di Kecamatan Koto Tangah Padang [Undergraduate Thesis, Universitas Andalas]. E-Skripsi Universitas Andalas. Retrieved from http://scholar.unand.ac.id/14719/

Gonczarowski, Y.A., Nisan, N., Ostrovsky, R., \& Rosenbaum, W. (2019). A stable marriage requires communication. Games and Economic Behavior, 118, 626-647. https://doi.org/10.1016/j.geb.2018.10.013

Kriyantono, R. (2020). Teknik Praktis Riset Komunikasi Kuantitatif dan Kualitatif. Jakarta: Prenadamedia Group.

Latifa, R. (2015). Komitmen Beragama Islam Memprediksi Stabilitas Perkawinan. $\begin{array}{llll}\text { Tazkiya: Journal of } & \text { 3(1), }\end{array}$ https://doi.org/10.15408/tazkiya.v20i1.9191

Luthfi, M. (2017). Komunikasi Interpersonal Suami dan Istri Dalam Mencegah Perceraian di Ponorogo. ETTISAL Journal of Communication, 2(1), 51. https://doi.org/10.21111/ettisal.v2i1.1413

Li, T., \& Fung, H. H. (2011). The Dynamic Goal Theory of Marital Satisfaction. Review of General Psychology, 15(3), 246-254. https://doi.org/10.1037/a0024694

Maulina, N., Atika, Ramadhani, M.M. (2020). Hubungan Komunikasi dengan Kepuasan Pernikahan pada Ibu Rumah Tangga Penggemar Tayangan Drama Korea. [Unpublished Research Paper], Universitas Lambung Mangkurat.

Moorman, S. M. (2011). The importance of feeling understood in marital conversations about end-of-life health care. Journal of Social and Personal Relationships, 28(1), 100-116. https://doi.org/10.1177/0265407510386137

Rakhmat, J. (2007). Psikologi Komunikasi. Bandung: PT. Remaja Rosda Karya.

Robinson, L.C dan Blanton, P. W. (2003). Material Strengths in Enduring Marriages. Journal of Family Relations, 42(1), 38-45. 
Seiter, N.S., Thompson R.G.L., Henry, K.L. (2019). Couples' Communication Behaviors and Diurnal Cortisol Patterns. Journal of Family Issues, 40(18), 2871-2892. https://doi.org/10.1177/ 0192513X19868260

Srisusanti.E., \& Zulkaida.A. (2013). Studi Deskriptif Mengenai Faktor-Faktor yang Mempengaruhi Kepuasan Perkawinan pada Istri. UG Jurnal, 7(6), 8-12.

Stinson, M. A., Bermúdez, J. M., Gale, J., Lewis, D., Meyer, A. S., \& Templeton, G. B. (2017). Marital Satisfaction, Conflict Resolution Styles, and Religious Attendance Among Latino Couples: Using the Actor-Partner Interdependence Model. The Family Journal, 25(3), 215-223. https://doi.org/10.1177/1066480717710645

Taniguchi, H., \& Kaufman, G. (2014). Gender role attitudes, troubles talk, and marital satisfaction in Japan. Journal of Social and Personal Relationships, 31(7), 975-994. https://doi.org/10.1177/0265407513516559

Van Den Troost, A., Vermulst, A.A., Gerris, J.R.M, dan Matthijs, K. (2005). The Dutch Marital Satisfaction and Communication Questionnaire: A Validation study. Psychologica Belgica, 45(3), 185 -206. DOI: http://doi.org/10.5334/pb-45-3-185

Vangelisti, L.A. (2004). Handbook of Family Communication. London: Mahwah.

Yucel, D. (2017). Work-family Balance and Marital Satisfaction: The Mediating Effects of Mental and Physical Health. Society and Mental Health, 7(3), 175-195. https://doi.org/10.1177/2156869317713069 